\title{
PENGARUH LOAN TO DEPOSIT RATIO, NET INTEREST MARGIN DAN INFLASI TERHADAP PROFITABILITAS
}

\author{
Ni Luh Putu Sugiantari ${ }^{1}$ \\ I Made Dana ${ }^{2}$ \\ ${ }^{1,2}$ Fakultas Ekonomi dan Bisnis Universitas Udayana (Unud), Bali, Indonesia \\ email: niluhputusugiantari97@yahoo.com
}

\begin{abstract}
ABSTRAK
Profitabilitas merupakan kemampuan perusahaan memperoleh laba dalam hubungannya dengan penjualan, total aktiva maupun modal sendiri. ROA dipilih sebagai rasio dari Profitabilitas, karena ROA digunakan untuk mengukur kemampuan manajemen bank dalam memperoleh keuntungan yang dihasilkan dari total aset bank yang bersangkutan. Tujuan dari penelitian ini adalah untuk mengetahui pengaruh LDR, NIM, dan Inflasi terhadap Profitabilitas (ROA). Penelitian menggunakan pendekatan asosiatif kausal yang dilakukan pada PT. Bank Pembangunan Daerah Bali periode 2009-2017. Metode pengumpulan data dalam penelitian menggunakan metode observasi nonparticipant. Teknik analisis yang digunakan adalah regresi linier berganda yang diolah dengan program SPSS. Hasil penelitian menunjukkan bahwa Loan to Deposit Ratio berpengaruh positif dan tidak signifikan terhadap ROA, Net Interest Margin berpengaruh positif dan signifikan terhadap ROA dan Inflasi berpengaruh positif dan tidak signifikan terhadap ROA.
\end{abstract}

Kata Kunci : inflasi, LDR, NIM, profitabilitas

\begin{abstract}
Profitability is the ability of a company to earn profits in relation to sales, total assets and own capital. ROA is chosen as the ratio of profitability, because ROA is used to measure the ability of bank management to obtain profits generated from the total assets of the bank concerned. The purpose of this study was to determine the effect of LDR, NIM, and Inflasi on Profitability (ROA). The study used a causal associative approach conducted at PT. Regional Development Bank of Bali for the period 2009-2017. The method of collecting data in research uses nonparticipant observation methods. The analysis technique used is multiple linear regression which is processed using the SPSS program. The results showed that the Loan to Deposit Ratio had a positive and not significant effect on ROA, Net Interest Margin had a positive and significant effect on ROA and Inflasi had a positive and not significant effect on ROA.
\end{abstract}

Keywords: Inflation, LDR, NIM, profitability 


\section{PENDAHULUAN}

Pembangunan ekonomi tidak dapat dipisahkan dari sektor perbankan. Hal ini karena bank adalah salah satu sarana yang memiliki peran penting dalam kegiatan ekonomi, di mana peran penting seperti, sebagai lembaga intermediasi yang mengumpulkan dan mendistribusikan dana masyarakat secara efektif dan efisien. Bank juga memiliki fungsi sebagai agen kepercayaan, yang berarti bahwa kegiatan usaha bank bergantung pada kepercayaan publik. Dalam rangka mempertahankan kepercayaan dari masyarakat maka bank harus mampu mempertahankan, meningkatkan dan mempertahankan kinerja keuangannya tetap baik (Hartono, 2017).

Profitabilitas merupakan indikator yang paling penting untuk mengukur kinerja suatu bank (Masdupi \& Defri, 2012). Pernyataan tersebut didukung oleh Avrita dan Pangestuti (2016) yang menyatakan bahwa salah satu cara untuk menentukan tingkat kesehatan kinerja keuangan suatu bank adalah dengan mengukur kinerja profitabilitas bank. Maksud dan tujuan dari analisis profitabilitas adalah untuk mengukur tingkat efisiensi usaha dan kemampuan perolehan laba yang dicapai oleh bank yang bersangkutan (Karuniawati, 2017). Oleh karena itu bank perlu menjaga profitabilitas agar tetap stabil atau bahkan meningkat (Prasetyo \& Darmayanti, 2015).

Mengukur tingkat profitabilitas merupakan hal yang sangat penting, hal ini bertujuan untuk menjamin apakah keuntungan yang ditargetkan oleh perusahaan dalam beberapa periode telah tercapai. Peraturan BI No.13/1/PBI/2011 tentang Penilaian Tingkat Kesehatan Bank Umum menunjukkan bahwa profitabilitas yangmerupakan salah satu unsur utama dalam penentuan tingkat kesehatan bank adalah rasio Return On Assets (ROA). Menurut Dietrich dan Wanzenried (2009). ROA mencerminkan kemampuan manajemen bank dalam seberapa efektif suatu bank dalam mengelola asetnya untuk menghasilkan suatu keuntungan. Anggadini dan Tarsiah (2017) menyatakan bahwa ROA (Return On Assets) merupakan rasio yang digunakan untuk mengukur kemampuan manajemen bank dalam memperoleh keuntungan (laba sebelum pajak) yang dihasilkan dari rata-rata total aset bank yang bersangkutan. Menurut Harun (2016), semakin besar ROA/Return On Asset menunjukkan kinerja keuangan yang semakin baik, karena tingkat pengembalian (return) semakin besar. Apabila ROA/Return On Asset meningkat, berarti profitabilitas perusahaan meningkat, sehingga dampak akhirnya adalah peningkatan kesejahteraan yang dinikmati oleh pemegang saham. Pernyataan tersebut didukung oleh Miadalyni dan Dewi (2013), bahwa semakin besar ROA menjadikan kinerja perusahaan lebih baik, karena tingkat pengembaliannya semakin besar.

Rasio ROA PT. Bank Pembangunan Daerah Bali periode tahun 2009 sampai tahun 2017 dapat ditunjukkan pada Tabel 1. Dapat diketahui bahwa ROA berfluktuasi selama delapan periode yaitu dari tahun 2009 sampai tahun 2017, dimana dari tahun 2009-2011 ROA terus menerus mengalami penurunan lalu meningkat ditahun 2012 menjadi 4,28\% dan menurun kembali hingga tahun 2015 menjadi 3,33\%. ROA meningkat kembali tahun 2016 menjadi 3,76\% dan mengalami penurunan tahun 2017 menjadi 3,16\%. Berdasarkan Surat Edaran 
Bank Indonesia No.6/23/DPNP tanggal 31 Mei 2004, Bank Indonesia menetapkan perolehan laba cukup tinggi, atau rasio ROA berkisar antara 0,5\% sampai dengan 1,25\%. Perolehan laba PT. Bank Pembangunan Daerah Bali berada pada tingkat wajar, namun berfluktuasinya ROA menunjukkan bahwa PT. Bank Pembangunan Daerah Bali mengalami kesulitan untuk menjaga stabilitas pertumbuhan laba di setiap tahunnya.

Tabel 1.

Return On Asset (ROA) PT. Bank Pembangunan Daerah Bali Periode 20092017

\begin{tabular}{cc}
\hline Tahun & ROA (\%) \\
\hline 2009 & 4,24 \\
2010 & 3,98 \\
2011 & 3,54 \\
2012 & 4,28 \\
2013 & 3,97 \\
2014 & 3,92 \\
2015 & 3,33 \\
2016 & 3,76 \\
2017 & 3,16 \\
\hline
\end{tabular}

Sumber: PT. Bank Pembangunan Daerah Bali, 2018

Wiagustini (2014: p. 210), untuk menilai kinerja keuangan sebuah perbankan umumnya digunakan enam aspek penilaian yaitu CAMELS (capital, asset, management, earning, liquidity dan sensitivity to market risk). Aspek capital meliputi Capital Adequacy Ratio (CAR), aspek asset meliputi Non Performing Loan (NPL), earning meliputi Net Interest Margin (NIM) dan Biaya Operasional terhadap Pendapatan Operasional (BOPO), sedangkan aspek liquidity meliputi Loan to Deposit Ratio (LDR). Dua dari enam aspek tersebut yaitu earning dan liquidity dinilai dengan menggunakan rasio keuangan yang digunakan dalam penelitian.

Untuk mencapai profitabilitas yang maksimum, bank sebagai lembaga intermediasi harus mampu membangun dan menjaga kepercayaan dari masyarakat. Pengelolan likuiditas yang baik berdampak terhadap kepercayaan masyarakat yang akan membantu kelangsungan operasional maupun keberadaan bank tersebut (Prasetyo \& Darmayanti, 2015). Salah satu pengukuran untuk mengukur likuiditas perbankan adalah dengan menggunakan Loan to Deposit Ratio (LDR) (Puspitasari et al., 2015). Pernyataan tersebut didukung oleh Hartono (2016), bahwa LDR dikenal sebagai salah satu cara untuk mengukur tingkat likuiditas bank. Lebih jelasnya oleh Pamularsih (2015) Loan to Deposit Rasio adalah rasio kinerja bank untuk mengukur likuiditas bank dalam memenuhi kebutuhan dana yang ditarik oleh masyarakat dalam bentuk tabungan, giro dan deposito. Kemudian Kristianti dan Yovin (2016) menyatakan semakin tinggi LDR, dana yang lebih tinggi dapat disalurkan ke dana pihak ketiga. Dengan distribusi dana pihak ketiga, laba bank (ROA) akan meningkat.

Menurut hasil penelitian Avrita dan Pangestuti (2016) menyatakan bahwa LDR berpengaruh negatif terhadap variabel ROA pada Bank Non Go Public. Hasil penelitian Ismaulina dan Zulfadhli (2016) menemukan bahwa LDR berpengaruh negatif dan tidak signifikan terhadap ROA. Hasil penelitian tersebut 
didukung oleh Oktavianus (2016) bahwa LDR berpengaruh negatif terhadap profitabilitas (ROA) pada Perusahaan Perbankan Di Bursa Efek Indonesia.Berbanding terbalik dengan hasil penelitian Anjani dan Purnawati (2014) bahwa LDR berpengaruh positif dan signifikan terhadap profitabilitas (ROA) pada bank BPR Konvensional di Indonesia. Pernyataan tersebut didukung oleh Puspitasari et al. (2015) bahwa LDR berpengaruh positif signifikan terhadap profitabilitas (ROA). Sudiyanto dan Suroso (2010), Pauzi (2011), Prastiningtyas (2010), Adnyani (2011), Fitriyana (2011), Septiani dan Lesatari (2016) dan Bernardin (2016) menyatakan bahwa LDR berpengaruh Positif dan tidak signifikan terhadap ROA.

Tabel 2.

Rasio LDR PT. Bank Pembangunan Daerah Bali Periode Periode 2009-2017

\begin{tabular}{cc}
\hline Tahun & LDR (\%) \\
\hline 2009 & 104,41 \\
2010 & 93,31 \\
2011 & 82,73 \\
2012 & 80,60 \\
2013 & 87,87 \\
2014 & 96,41 \\
2015 & 97,32 \\
2016 & 102,75 \\
2017 & 92,57 \\
\hline
\end{tabular}

Sumber: PT. Bank Pembangunan Daerah Bali, 2018

Rasio LDR PT. Bank Pembangunan Daerah Bali periode tahun 2009 sampai tahun 2017 dapat ditunjukan pada Tabel 2. Dapat diketahui bahwa LDR mengalami penurunan dari tahun 2009 sampai tahun 2012, LDR kemudian meningkat pada tahun 2013 sampai tahun 2016 dan mengalami penurunan pada tahun 2017 menjadi 92,57\%. Berdasarkan Surat Edaran Bank Indonesia No.6/23/DPNP tanggal 31 Mei 2004, Bank Indonesia menyatakan bahwa LDR berkisar antara $85 \%$ sampai dengan 100\%. PT. Bank Pembangunan Daerah Bali dianggap tidak sehat pada tahun 2009 dan tahun 2016 karena LDR berada diatas 100\%, dan pada tahun 2011, tahun 2012 karena LDR berada dibawah 85\%.

Keuntungan yang diperoleh bank sebagai imbalan dari pemberian kredit adalah pendapatan bunga. Pendapatan bunga bersih diperoleh dari pendapatan operasional bank karena bunga tersebut diperoleh dari kegiatan utamanya dalam menyalurkan kredit. Sehingga rasio NIM berpengaruh dalam pemberian kredit. Semakin tinggi NIM sehingga kemungkinan suatu bank dalam kondisi bermasalah semakin kecil dan menunjukkan kesehatan bank semakin meningkat, sesuai dengan kriteria penilaian tingkat kesehatan bank yang dikeluarkan oleh Bank Indonesia (Pamularsih, 2015).

Nadi (2016) menyatakan bahwa NIM merupakan rasio kemampuan manajemen bank dalam mengelola aktiva produktif untuk menghasilkan pendapatan bunga bersih semakin besar. Semakin tinggi NIM menunjukkan semakin efektif bank dalam penempatan aktiva perusahaan dalam bentuk kredit, sehingga ROA bank akan semakin meningkat, semakin besar NIM suatu bank, maka semakin besar juga ROA yang diperoleh bank tersebut, yang berarti kinerja keuangan bank semakin membaik dan meningkat. 
Rasio NIM PT. Bank Pembangunan Daerah Bali periode tahun 2009 sampai tahun 2017 dapat ditunjukkan pada Tabel 1.3. Dapat diketahui bahwa rasio NIM mengalami penurunan dari tahun 2009 sampai tahun 2011 menjadi 7,79\%. NIM berfluktuasi dari tahun 2012 sampai tahun 2017 menjadi 7,28\%. Berdasarkan Surat Edaran Bank Indonesia No.6/23/DPNP tanggal 31 Mei 2004, Bank Indonesia menetapkan marjin bunga bersih cukup tinggi atau rasio NIM berkisar antara 1,5\% sampai dengan 2\%. Presentase NIM PT. Bank Pembangunan Daerah Bali tahun 2009-2017 secara keseluruhan berada diatas 2\%, mencerminkan bahwa kemampuan rentabilitas sangat tinggi untuk mengantisipasi kerugian.

Tabel 3.

Rasio NIM PT. Bank Pembangunan Daerah Bali Periode 2009-2017

\begin{tabular}{cc}
\hline Tahun & NIM (\%) \\
\hline 2009 & 9,19 \\
2010 & 8,65 \\
2011 & 7,79 \\
2012 & 7,50 \\
2013 & 7,63 \\
2014 & 7.68 \\
2015 & 6,85 \\
2016 & 7,75 \\
2017 & 7,28 \\
\hline
\end{tabular}

Sumber: PT. Bank Pembangunan Daerah Bali, 2018

Hasil penelitian sebelumnya yang dilakukan oleh Pamularsih (2015) pada sektor perbankan yang terdaftar di Bursa Efek Indonesia periode tahun 2009-2013 menyatakan bahwa NIM berpengaruh negatif dan tidak signifikan terhadap ROA. Hasil penelitian tersebut berbanding terbalik dengan Kristianti dan Yovin (2016), Manurung (2015), Anggadini dan Tarsiah (2017), Avrita dan Pangestuti (2016) yang menemukan hasil bahwa NIM berpengaruh positif terhadap ROA.

PT. Bank Pembangunan Daerah Bali dalam kegiatan bisnisnya dapat dipengaruhi oleh faktor eksternal. Faktor eksternal yang terkait dengan kondisi makroekonomi dalam kegiatan bisnis PT. Bank Pembangunan Daerah Bali yaitu Inflasi. Menurut Dwijayanti dan Naomi (2016) tingginya angka inflasi dapat berdampak pada sektor perbankan. Oleh karena itu, bank Indonesia juga perlu menetapkan tingkat suku bunga (BI Rate) yang sesuai sebagai dasar atau patokan bank umum dan swasta untuk menentukansuku bunga mereka agar mereka dapat tetap likuid dan menguntungkan. Salah satu penyebab krisis yang dialami oleh Indonesia yaitu inflasi yang berkepanjangan.Wibowo dan Syaichu (2013) menyatakan bahwa inflasi dapat berpengaruh buruk bagi perekonomian. Apabila terjadi integrasi yang parah tak terkendali (hiperinflasi) maka keadaan ekonomi menjadi kacau dan ekonomi pun lesu. Hal ini menghasilkan minat masyarakatuntuk menabung, atau berinvestasi dan berproduksi menjadi berkurang. .

Hasil penelitian Floros dan Tan (2012) menemukan bahwa inflasi berpengaruh positif terhadap profitabilitas di sektor perbankan China yang mencerminkan fakta bahwa inflasi di China dapat sepenuhnya diantisipasi sedangkan suku bunga disesuaikan. Hasil penelitian ini sejalan dengan Dewi 
(2018) bahwa Inflasi berpengaruh positif dan signifikan terhadap profitabilitas (ROA). Berbanding terbalik dengan hasil penelitian Kalengkongan (2013) dan Dwijayanti dan Naomi (2016) menemukan bahwa inflasi berpengaruh signifikan dan negatif terhadap profitabilitas. Penelitian Alim (2013) dan Prastowo, Malavia dan Wahono (2018) menemukan hasil bahwa Inflasi berpengaruh positif dan tidak signifikan terhadap ROA pada Bank Syariah di Indonesia. Persentase tingkat inflasi Kota Denpasar than periode 2009-2017 dapat ditunjukkan pada Tabel 4.

Tabel 4.

Tingkat Inflasi Kota Denpasar Provinsi Bali Periode 2009-2017

\begin{tabular}{cc}
\hline Tahun & Tingkat Inflasi (\%) \\
\hline 2009 & 4,37 \\
2010 & 8,10 \\
2011 & 3,75 \\
2012 & 4,71 \\
2013 & 7,35 \\
2014 & 8,03 \\
2015 & 2,70 \\
2016 & 2,94 \\
2017 & 3,31 \\
\hline
\end{tabular}

Sumber : https://bali.bps.go.id, 2018

PT. Bank Pembangunan Daerah Bali merupakan salah satu jenis perbankan yang menjembatani peranan keuangan antar pihak yang memiliki kelebihan dana dengan pihak yang mengalami kekurangan dana di Bali. Menurut Dwinanda dan Wiagustini (2014), PT. Bank Pembangunan Daerah Bali merupakan salah satu bank lokal yang berstatus umum dengan aktivitas nasional maupun internasional. Prasetyo dan Darmayanti (2015) menyatakan bahwa sebagai salah satu bank yang mempunyai visi untuk menjadi bank yang sehat, tangguh, dan terpercaya dalam persaingan global, maka PT. Bank Pembangunan Daerah Bali perlu memperhatikan kinerjanya, salah satu faktor penilaiannya adalah profitabilitas.

Beragamnya hasil temuan penelitian tentang pengaruh LDR, NIM, dan Inflasi terhadap profitabilitas (ROA), dan melihat pentingnya penilaian terhadap kinerja keuangan bank untuk pemaksimuman profitabilitas bank. Maka akan dikaji kembali penelitian untuk mengetahui bagaimana pengaruh rasio LDR, NIM, dan Inflasi terhadap Profitabilitas (ROA) yang terjadi pada PT. Bank Pembangunan Daerah Bali Periode 2009-2017.

Profitabilitas merupakan kemampuan yang dimiliki oleh suatu perusahaan dalam menghasilkan laba. Rasio ini digunakan untuk mengukur tingkat efisiensi usaha dan profitabilitas yang dicapai oleh bank yang bersangkutan (Kasmir, 2012: p. 327). Fahmi (2016: p. 80) menyatakan bahwa profitabilitas merupakan mengukur efektifitas manajemen secara keseluruhan yang ditujukan oleh besar kecilnya tingkat keuntungan yang diperoleh dalam hubungannya dengan penjualan maupun investasi. Semakin baik rasio profitabilitas maka semakin baik menggambarkan kemampuan tingginya perolehan keuntungan perusahaan. Menurut Ubaidillah (2016), Profitabilitas sangat penting bagi perbankan, karena digunakan sebagai indikator untuk mengukur efesiensi perusahaan dalam menghasilkan keuntungan dengan memanfaatkan aktiva yang dimilikinya. 
Menurut Masdupi dan Defri (2012) untuk mengukur profitabilitas bank, menggunakan rasio profitabilitas karena rasio profitabilitas sudah mencakup rasio utang, rasio aktivitas maupun rasio likuiditas yang terdiri dari ROE (Return On Equity) yaitu rasio yang menggambarkan besarnya kembalian atas modal untuk menghasilkan keuntungan, dan ROA (Return On Asset) yaitu rasio yang menunjukkan kemampuan dari keseluruhan aset yang ada dan digunakan untuk menghasilkan keuntungan. Menurut Avrita dan Pangestuti (2016) ROA lebih memfokuskan pada kemampuan perusahaan untuk memperoleh pendapatan dalam operasi perusahaan secara keseluruhan, sehingga semakin besar ROA akan semakin baik, karena menunjukan tingkat kembalian (return) yang semakin besar.

Puspitasari et al. (2015), likuiditas memainkan peran penting dalam mengelola kinerja perbankan. Sulindawati, Yuniarta dan Purnawati (2017: p. 135), rasio likuiditas merupakan rasio yang diperlukan dalam menganalisis laporan keuangan perusahaan, karena rasio likuiditas merupakan rasio yang menunjukkan kemampuan perusahaan dalam memenuhi kewajiban jangka pendek yang harus segera dipenuhi oleh perusahaan. Lebih singkatnya lagi, menurut Fahmi (2016: p. 58) rasio likuiditas (liquidity rastio) mengukur kemampuan perusahaan dalam memenuhi kewajiban jangka pendeknya. Rasio ini penting karena kegagalan dalam membayar kewajiban dapat menyebabkan kebangkrutan perusahaan.

Peling dan Sedana (2018) menyatakan bahwa untuk mencapai profitabilitas yang maksimum, bank sebagai lembaga intermediasi harus mampu melakukan pengelolan likuiditas yang baik dengan memperhatikan kualitas kredit yang diberikan. Loan to Deposit Ratio (LDR) adalah rasio yang digunakan untuk mengukur risiko likuiditas bank. Prasanjaya dan Ramanantha (2013) mengungkapkan bahwa kurangnya likuiditas adalah salah satu alasan utama kegagalan bank. LDR yang tinggi akan menunjukkan profitabilitas yang besar, karena kredit yang disalurkan oleh bank dapat dijalankan secara efektif.

Kristianti dan Yovin (2016), LDR adalah ukuran likuiditas yang mengukur jumlah dana yang ditempatkan dalam bentuk kredit dari dana yang dikumpulkan oleh bank (terutama dana publik). LDR lebih tinggi menunjukkan kondisi likuiditas perbankan lebih berisiko, sebaliknya lebih rendah LDR menunjukkan kurangnya kemanjuran bank untuk memperpanjang kredit. Semakin tinggi LDR, dana yang lebih tinggi dapat disalurkan ke dana pihak ketiga.

Berdasarkan Surat Edaran Bank Indonesia No.6/23/DPNP tanggal 31 Mei 2004, Bank Indonesia menyatakan bahwa LDR berkisar antara $85 \%$ sampai dengan $100 \%$.Jika angka rasio LDR berada dibawah $85 \%$ maka dapat dikatakan bahwa bank tersebut tidak dapat menyalurkan kembali dengan baik seluruh dana yang telah dihimpun. Jika rasio LDR bank mencapai lebih dari 100\% maka total kredit yang disalurkan oleh bank tersebut telah melebihi dana yang dihimpun. Menurut Septiani dan Lesatari (2016) pengelolaan dana masyarakat ini, bank dituntut untuk mampu menjaga likuiditasnya agar tetap mendapatkan kepercayaan dari masyarakat. Besar kecilnya LDR suatu bank akan mempengaruhi profitabilitas bank tersebut. 
Diva (2013), NIM digunakan untuk mengetahui pendapatan bunga bersih dalam 12 bulan yang mampu diperoleh bank apabila dibandingkan dengan ratarata produktif bank. Aktiva produktif yang diperhitungkan aktiva produktif yang memiliki kemampuan untuk menghasilkan bunga. Sehingga semakin besar perubahan NIM suatu bank maka semakin besar ROA yang diperoleh bank berarti kinerja bank tersebut semakin baik. Alper dan Anbar (2011), menyatakan bahwa NIM mengukur spread bunga bersih bank dan didefinisikan sebagai pendapatan bunga bersih terhadap total aset. Menurut Kristianti dan Yovin (2016) NIM menunjukkan nilai pendapatan bunga yang berasal dari kredit yang disalurkan oleh bank. Sebagai jenis usaha, bank merupakan perusahaan yang melakukan bisnis di bidang penyediaan pembiayaan kepada pihak lain. Dengan demikian keuntungan dari bank akan ditentukan oleh pendapatan bunga yang diperoleh. Kemampuan manajemen bank dalam mengendalikan jumlah biaya bunga dan dalam mengelola aset-aset produktif untuk membuat kepentingan akan mempengaruhi profitabilitas bank.

Pamularsih (2015), Net Interest Margin (NIM) menunjukkan kemampuan bank dalam menghasilkan pendapatan dari bunga dengan melihat kinerja bank dalam menyalurkan kredit, mengingat pendapatan operasional bank sangat tergantung dari selisih bunga dari kredit yang disalurkan. Pendapatan diperoleh dari bunga yang diterima dari pinjaman yang diberikan dikurangi dengan biaya bunga dari sumber dana yang dikumpulkan. Untuk dapat meningkatkan perolehan Net Interest Margin (NIM) maka perlu menekan biaya dana, biaya dana adalah bunga yang dibayarkan oleh bank kepada masing-masing sumber dana bank yang bersangkutan. Menurut Acaravci dan Calim (2013), Variabel NIM didefinisikan sebagai pendapatan bunga bersih dibagi dengan total asset. Menurut Anjani dan Purnawati (2014), Net Interest Margin (NIM) merupakan rasio yang menunjukkan kemampuan manajemen bank dalam mengelola aktiva produktifnya untuk menghasilkan pendapatan bunga bersih. Net Interest Margin (NIM) adalah rasio antara aktiva produktif terhadap pendapatan bunga. Berdasarkan Surat Edaran Bank Indonesia No.6/23/DPNP tanggal 31 Mei 2004, Bank Indonesia menetapkan marjin bunga bersih cukup tinggi atau rasio NIM berkisar antara $1,5 \%$ sampai dengan $2 \%$.

Inflasi adalah kecenderungan naiknya harga barang dan jasa pada umumnya yang berlangsung secara terus menerus. Jika harga barang dan jasa di dalam negeri meningkat, maka inflasi mengalami kenaikan. Naiknya harga barang dan jasa tersebut menyebabkan turunnya nilai uang. Dengan demikian, inflasi dapat juga diartikan sebagai penurunan nilai uang terhadap nilai barang dan jasa secara umum. (https://www.bps.go.id., diakses pada 12/11/2018). Menurut Zuniarti (2013) inflasi adalah suatu gejala naiknya harga secara terus-menerus (berkelanjutan) terhadap sejumlah barang. Kenaikan yang sifatnya sementara tidak dikatakan inflasi dan kenaikan harga terhadap satu jenis komoditi juga tidak dikatakan inflasi.

Muda, Shaharuddin dan Embaya (2013), tingkat inflasi (INF) didefinisikan sebagai kenaikan umum berkelanjutan di harga dalam suatu perekonomian dimana tingkat inflasi yang tinggi dikaitkan dengan biaya yang lebih tinggi serta 
pendapatan yang lebih tinggi. Alper dan Anbar (2011), jika tingkat inflasi diantisipasi, bank dapat menyesuaikan tingkat suku bunga dalam rangka meningkatkan pendapatan dari biaya. Sebaliknya, jika tingkat inflasi tidak diantisipasi, bank tidak dapat membuat penyesuaian yang tepat dari tingkat suku bunga yang biaya dapat meningkat lebih cepat daripada pendapatan. Menurut Hidayati (2014) Indikator yang sering digunakan untuk mengukur tingkat inflasi adalah Indeks Harga Konsumen (IHK). Perubahan IHK dari waktu ke waktu menunjukkan pergerakan harga dari paket barang dan jasa yang dikonsumsi masyarakat.

Kasmir (2013: p. 319) LDR adalah rasio yang digunakan untuk mengetahui kemampuan bank dalam membayar kembali kewajiban kepada para nasabah yang telah menanamkan dana dengan kredit-kredit yang telah diberikan para debiturnya. Menurut Miadalyni dan Dewi (2013), LDR disebut juga rasio kredit terhadap total dana pihak ketiga yang digunakan untuk mengukur dana pihak ketiga yang disalurkan dalam bentuk kredit. Semakin tinggi LDR/Loan to Deposit Ratio suatu bank maka semakin besar kredit yang disalurkan, yang akan meningkatkan pendapatan bunga bank dan akan mengakibatkan kenaikan laba sehingga LDR/Loan to Deposit Ratio berpengaruh positif terhadap ROA/Return On Asset (Harun, 2016).

Penelitian Masdupi dan Defri (2012), Prasanjaya dan Ramanantha (2013), Lall (2014), Anjani dan Purnawati (2014), Alshatti (2015), Widowati dan Suryono (2015), Chou dan Buchdadi (2016), Kristianti dan Yovin (2016), Mismiwati (2016), Septiani dan Lesatari (2016), Harun (2016), Irfan, Santoso dan Effendi (2016), Hartono (2017), Karuniawati (2017), Peling dan Sedana (2018), menemukan hasil bahwa LDR berpengaruh positif dan signifikan terhadap ROA. Berdasarkan teori dan hasil dari penelitian yang telah dilakukan sebelumnya, maka dapat dirumuskan hipotesis sebagai berikut:

$\mathrm{H}_{1}$ : Rasio LDR berepengaruh positif dan signifikan terhadap ROA.

Mengingat kegiatan utama perbankan pada prinsipnya adalah bertindak sebagai perantara yaitu menghimpun dana dan menyalurkan dana masyarakat maka biaya dan pendapatan operasional bank didominasi oleh biaya dan ahsil bunga Dendawijaya (2005). Menurut Diva (2013), Net Interest Margin (NIM) digunakan untuk mengukur kemampuan manajemen bank dalam mengelola aktiva produktifnya untuk menghasilkan pendapatan bunga bersih. Pendapatan bunga bersih diperoleh dari pendapatan bunga dikurangi beban bunga. Rasio ini menunjukkan kemampuan bank dalam memperoleh pendapatan operasionalnya dari dana yang ditempatkan dalam bentuk pinjaman (kredit). Semakin tinggi NIM menunjukkan semakin efektif bank dalam menempatkan aktiva produktif dalam bentuk kredit. Standar yang ditetapkan Bank Indonesia untuk rasio NIM adalah $6 \%$ keatas. Semakin besar rasio ini maka semakin meningkat pendapatan bunga atas aktiva produktif yang dikelola bank sehingga kemungkinan bank dalam kondisi bermasalah semakin kecil. Dapat disimpulkan bahwa semakin besar Net Interest Margin (NIM) suatu perusahaan, maka semakin besar pula Return On Asset (ROA) perusahaan tersebut, yang berarti kinerja keuangan tersebut semakin membaik atau meningkat. Begitu juga sebaliknya, jika net interst margin (NIM) semakin kecil, Return On Asset (ROA) juga akan semakin kecil. 
Penelitian Lall (2014), Bilian dan Purwanto (2014), Kristianti dan Yovin (2016), Okavianus (2016), Avrita dan Pangestuti (2016), Nadi (2016) dan Dewi (2018), menunjukkan hasil bahwa NIM memiliki hubungan yang positif dan signifikan terhadap profitabilitas (ROA). Berdasarkan teori dan hasil dari penelitian yang telah dilakukan sebelumnya, maka dapat dirumuskan hipotesis sebagai berikut:

$\mathrm{H}_{2}$ : Rasio NIM berpengaruh positif dan signifikan terhadap ROA

Di dalam perekonomian kita, sebagian besar harga cenderung naik seiring berjalannya waktu. Kenaikan tingkat harga secara keseluruhan ini disebut dengan inflasi Mankiw, Quah dan Peter (2012: p. 141). Inflasi dapat berpengaruh buruk bagi perekonomian. Apabila terjadi integrasi yang parah tak terkendali (hiperinflasi) maka keadaan ekonomi menjadi kacau dan ekonomi pun lesu. Hal ini menghasilkan minat masyarakatuntuk menabung, atau berinvestasi dan berproduksi menjadi berkurang. Harga meningkat dengan cepat, masyarakat akan kewalahan dan mengimbangi harga kebutuhan sehari-hari yang terus meroket. Kenaikan bunga kredit tentu akan menghambat pertumbuhan kredit itu sendiri. Sementara pendapatan dari sektor kredit akan menjadi kecil. Hal ini berimbas kepada profitabilitas bank yang bersangkutan (Wibowo \& Syaichu, 2013).

Penelitian Dwijayanti dan Naomi (2016), Kalengkongan (2013), Muda et al. (2013), Zuniarti (2013), Duraj dan Moci (2015), dan Alper dan Anbar (2011) hasilnya menunjukkan bahwa inflasi berpengaruh negatif dan signifikan terhadap ROA. Berdasarkan teori dan hasil dari penelitian yang telah dilakukan sebelumnya, maka dapat dirumuskan hipotesis sebagai berikut:

$\mathrm{H}_{3}$ : Inflasi berpengaruh negatif dan signifikan terhadap ROA.

\section{METODE PENELITIAN}

Penelitian ini dilakukan pada PT. Bank Pembangunan Daerah Bali yang beralamat di Jalan Raya Puputan Niti Mandala, Renon, Panjer. Lokasi ini dipilih karena terdapat fenomena ROA yang berfluktuasi pada PT. Bank Pembangunan Daerah Bali periode tahun 2009-2017.

Obyek pada penelitian ini adalah Profitabilitas PT. Bank Pembangunan Daerah Bali periode 2009-2017 yang diproyeksikan dengan ROA (Return On Asset) yang dihubungkan dengan menggunakan Loan to Deposit Ratio, Net Interest Margin dan Inflasi.

ROA merupakan rasio perbandingan laba sebelum pajak dengan rata-rata total asset pada PT. Bank Pembangunan Daerah Bali Periode 2009-2017. Satuan ukurannya adalah persentase. ROA dapat dirumuskan sebagai berikut (Wiagustini, 2014: p. 90) :

$$
R O A=\frac{\text { Laba Sebelum Pajak }}{\text { Total Aset }} \times 100 \%
$$

Loan to Deposit Rasio atau LDR merupakan rasio perbandingan kredit dengan dana pihak ketiga pada PT. Bank Pembangunan Daerah Bali periode 2009-2017. Rasio LDR digunakan untuk mengukur kemampuan bank dalam membayar kewajiban jangka pendeknya. Satuan ukurnya adalah persentase. LDR dapat dirumuskan sebagai berikut (SE BI No.6/ 23./DPNP tanggal 31 Mei 2004): 
$L D R=\frac{\text { Kredit }}{\text { Dana Pihak Ketiga }} \times 100 \%$

NIM merupakan rasio perbandingan antara pendapatan bunga bersih dengan rata-rata aktiva produktif. Satuan ukurnya adalah persentase. Rasio ini digunakan untuk mengukur kemampuan manajemen bank dalam mengelola aktiva produktifnya untuk menghasilkan pendapatan bunga bersih pada PT. Bank Pembangun Daerah Bali periode 2009-2017. NIM dapat dirumuskan sebagai berikut (SE BI No.6/ 23./DPNP tanggal 31 Mei 2004) :

$N I M=\frac{\text { PendapatanBungaBersih }}{\text { Rata-rata Aktiva Produktif }} \times 100 \%$.

Inflasi merupakan kecenderungan naiknya harga suatu barang atau jasa yang terjadi secara terus menerus. Naiknya harga barang atau jasa mengakibatkan turunnya nilai uang. Tingkat inflasi diukur dengan Indeks Harga Konsumen Provinsi Bali Kota Denpasar periode 2009-2017.

Populasi dan sampel dalam penelitian ini adalah PT. Bank Pembangunan Daerah Bali yaitu berupa data laporan keuangan tahunan selama periode 20092017 dengan menggunakan teknik sampling jenuh.

Teknik Analisis Regresi Linier Berganda digunakan dalam penelitian ini karena variabel terikat dipengaruhi oleh lebih dari satu variabel bebas dan untuk mengatahui arah dan besarnya pengaruh variabel bebas yang akan diteliti pada PT. Bank Pembangunan Daerah Bali Kantor dari tahun 2009-2017, yang dimana LDR, NIM dan Inflasi sebagai variabel bebas dan ROA sebagai variabel terikat. Persamaan regresi linier berganda secara sistematis dapat dirumuskan sebagai berikut :

$$
Y=\alpha+\beta_{1} X 1+\beta_{2} \mathrm{X} 2+\beta_{3} \mathrm{X} 3+\mathrm{ei} .
$$

Keterangan :

$\begin{array}{ll}\mathrm{Y} & =\text { ROA } \\ \alpha & =\text { Konstanta } \\ \beta_{1}, \beta_{2}, \beta_{3} & =\text { Koefisien Regresi } \\ \mathrm{X}_{1} & =\text { LDR } \\ \mathrm{X}_{2} & =\text { NIM } \\ \mathrm{X}_{3} & =\text { Inflasi } \\ \mathrm{ei} & =\text { Standar error }\end{array}$

\section{HASIL DAN PEMBAHASAN}

Pengujian statistik deskriptif dilakukan untuk memberikan gambaran atau deskripsi suatu data yang dilihat dari nilai rata-rata (mean), standar deviasi, nilai minimum dan nilai maksimum. Hasil analisis deskripsi dari penelitian ini dapat ditunjukkan pada Tabel 5.

Jumlah data yang digunakan sebanyak 9 dalam periode sembilan tahun (2009-2017) dengan nilai rata-rata (mean) dari ROA PT. Bank Pembangunan Daerah Bali sebesar 3.7967 persen. Standar deviasi ROA 0.25749. Nilai ROA terendah yang dimiliki adalah 3.33 persen tahun 2015 dan nilai tertinggi adalah 4.24 persen di tahun 2009 . 
Tabel 5.

Hasil Analisis Deskriptif Statistik

\begin{tabular}{cccccc}
\hline & N & Minimum & Maximum & Mean & $\begin{array}{c}\text { Std. } \\
\text { Deviation }\end{array}$ \\
\hline $\mathrm{Y} 1$ & 9 & 3,33 & & & \\
$\mathrm{X} 1$ & 9 & 82,73 & 104,41 & 93,7967 & 0.2574 \\
$\mathrm{X} 2$ & 9 & 6,85 & 9,19 & 7,9267 & 0.32386 \\
$\mathrm{X} 3$ & 9 & 2,70 & 8,10 & 4,9978 & 1.94579 \\
\hline
\end{tabular}

Sumber: Data diolah, 2018

Jumlah data yang digunakan sebanyak 9 dalam periode sembilan tahun (2009-2017) dengan nilai rata-rata (mean) dari LDR PT Bank Pembangunan Daerah Bali sebesar 95.1400 persen. Standar deviasi LDR 6.32386. Nilai LDR terendah yang dimiliki adalah 82.73 persen tahun 2011 dan nilai tertinggi adalah 104.41 persen di tahun 2009.

Jumlah data yang digunakan sebanyak 9 dalam periode sembilan tahun (2009-2017) dengan nilai rata-rata (mean) dari NIM PT Bank Pembangunan Daerah Bali sebesar 7.9267 persen. Standar deviasi NIM0.65479. Nilai NIM terendah yang dimiliki adalah 6.85 persen tahun 2015dan nilai tertinggi adalah 9.19 persen di tahun 2019 .

Jumlah data yang digunakan sebanyak 9 dalam periode sembilan tahun (2009-2017) dengan nilai rata-rata (mean) dari inflasi PT. Bank Pembangunan Daerah Bali sebesar 4.9978 persen. Standar deviasi inflasi 1.94572. Nilai inflasi terendah yang dimiliki adalah 2.70 persen tahun 2015 dan nilai tertinggi adalah 8.10 persen di tahun 2010.

Analisis Regresi Linier Berganda digunakan untuk menunjukkan arah dan besarnya pengaruh antara LDR, NIM, dan Inflasi terhadap ROA pada PT. Bank Pembangunan Daerah Bali periode tahun 2009 - 2017 yang ditunjukkan dari masing-masing koefisien regresi variabel bebasnya secara parsial dengan menggunakan software SPSS 13.0. Hasil analisis regresi linier berganda penelitian ini dapat ditunjukkan pada Tabel 6 berikut ini :

Tabel 6.

Hasil Analisis Regresi Linier Berganda

\begin{tabular}{|c|c|c|c|c|c|c|c|c|}
\hline & \multirow[t]{2}{*}{ Model } & \multicolumn{2}{|c|}{$\begin{array}{l}\text { Unstandarized } \\
\text { Coefficients }\end{array}$} & \multirow{2}{*}{$\begin{array}{c}\text { Standardized } \\
\text { Coefficients } \\
\text { Beta }\end{array}$} & \multirow[b]{2}{*}{$\mathbf{T}$} & \multirow[b]{2}{*}{ Sig } & \multicolumn{2}{|c|}{$\begin{array}{l}\text { Collinearity } \\
\text { Statistic }\end{array}$} \\
\hline & & B. & Std. Error & & & & Tolerance & VIF \\
\hline \multirow[t]{4}{*}{1} & Constan & 0,240 & 0,537 & & & & & \\
\hline & LDR & 0,012 & 0,005 & 0,302 & 2,341 & 0,066 & 0,869 & 1150 \\
\hline & NIM & 0,274 & 0,054 & 0,697 & 5,076 & 0,004 & 0,768 & 1302 \\
\hline & Inflasi & 0,042 & 0,018 & 0,319 & 2,387 & 0,063 & 0,812 & 1232 \\
\hline
\end{tabular}

Sumber: Data diolah, 2018

Berdasarkan Tabel 6. maka diperoleh persamaan hasil regresi linier berganda sebagai berikut :

$$
\hat{\mathrm{Y}}=0,240+0,012 \mathrm{X}_{1}+0,274 \mathrm{X}_{2}+0,042 \mathrm{X}_{3}
$$

Keterangan : 


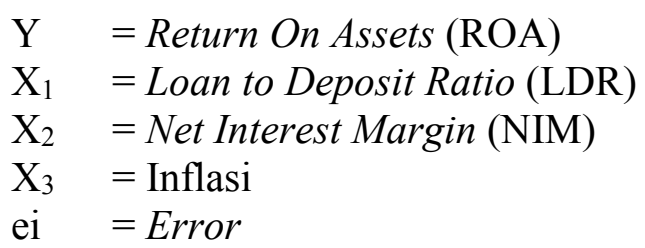

Uji normalitas bertujuan untuk menguji apakah dalam model regresi data yang digunakan dalam penelitiantelah berdistribusi normal. Dalam penelitian ini, untuk menguji apakah data berdistribusi normal atau tidak, dilakukan dengan Uji Komogorov-Sminarnov. Hasil uji normalitas pada Tabel 7 menunjukkan bahwa besarnya nilai Asymp.Sig. (2-tailed) residual adalah $0.867>$ level of signifikan $(\alpha=5 \%)$. Hal ini berarti data yang digunakan dalam model regresi telah berdistribusi normal.

Tabel 7.

Hasil Uji Normalitas

\begin{tabular}{llr}
\hline & & Unstandardized Residual \\
\hline & & 9 \\
Normal Parameters ab & Mean & 0,0000000 \\
& Std, Deviation & 0,06933727 \\
Most Extreme & Absolute & 0,199 \\
Differences & Positive & 0,198 \\
& Negatife & $-0,199$ \\
kolmogorov-Smirnov Z & & 0,598 \\
asymp, Sig, (2-tailed) & & 0,867 \\
\hline
\end{tabular}

Sumber: Data diolah, 2018

Uji Autokorelasi bertujuan untuk memprediksi ada atau tidaknya pengaruh data dari pengamatan sebelumnya dalam model regresi. Jika suatu model regresi mengandung gejala autokorelasi maka prediksi yang dilakukan dengan model regresi tersebut tidak baik, atau dapat memberikan hasil prediksi yang menyimpang. Uji Autokorelasi dapat dilakukan Uji Durbin Watson (DW). Jika nilai DW berada diantara DU dengan 4-DU berarti tidak ada autokorelasi. Hasil perhitungan statistik uji Durbin Watson (DW-test) dapat ditunjukkan pada Tabel 8 berikut:

Tabel 8.

Hasil Uji Autokorelasi

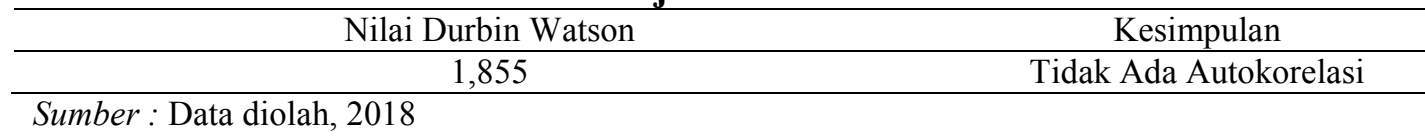

Berdasarkan hasil uji autokorelsi pada Tabel 8. diperoleh nilai DW sebesar 1.855. Tabel DW dengan level signifikan 5 persen, untuk $\mathrm{n}=9$ dan jumlah variabel bebas $(\mathrm{k})$ sebanyak 3 didapat $\mathrm{dL}$ sebesar 0,4548, dU sebesar 2,1282 dan 4-DU menjadi 1,8718. Nilai DW sebesar 1.855 terletak antara DU $(2,1282)$ dengan 4-DU $(1,8718)$ sehingga model bebas autokorelasi. 
Uji multikolinieritas bertujuan untuk menguji apakah dalam model ditemukan adanya korelasi antar variabel independen. Model regresi yang baik seharusnya tidak terjadi korelasi di antara variabel independen. Pada penelitian ini uji multikolinieritas dilakukan dengan melihat nilai Variance Inflation Factor (VIF) pada model regresi. Untuk mendeteksi ada atau tidaknya korelasi antar sesama variabel bebas dapat dilihat dari nilai tolerance dan nilai variance inflation factor (VIF). Jika nilai tolerance melebihi nilai 10 persen atau VIF kurang dari 10, maka dikatakan tidak ada multikolinieritas.

Tabel 9.

Hasil Uji Multikolinearitas

\begin{tabular}{cccc}
\hline Variabel Bebas & Tolerance & VIF & Keterangan \\
\hline LDR & 0,869 & 1,150 & Tidak Multikol \\
NIM & 0,768 & 1,302 & Tidak Multikol \\
Inflasi & 0,812 & 1,232 & Tidak Multikol \\
\hline
\end{tabular}

Sumber: Data diolah, 2018

Berdasarkan Tabel 9. hasil uji multikolinieritas, nilai Tolerance melebihi 10 persen dan nilai VIF tiga variabel independen yaitu LDR, NIM, dan Inflasi kurang dari nilai 10. Dengan demikian, dapat disimpulkan bahwa tidak ada masalah multikolinearitas antar variabel independen dalam model regresi.

Uji heteroskedastisitas digunakan untuk menguji apakah dalam model regresi terjadi ketidaksamaan varians dari residual satu pengamatanke pengamatan yang lain. Model regresi yang baik adalah yang homoskedastisitas atau tidak terjadi heteroskedastisitas.

Tabel 10.

Hasil Uji Heteroskedastisitas

\begin{tabular}{|c|c|c|c|c|c|}
\hline \multirow{2}{*}{ Model } & \multicolumn{2}{|c|}{ Unstandardized Coefficients } & \multirow{2}{*}{$\begin{array}{c}\text { Standardized } \\
\text { Coefficients } \\
\text { Beta }\end{array}$} & \multirow{2}{*}{$\mathbf{T}$} & \multirow{2}{*}{ Sig. } \\
\hline & B & Std. Error & & & \\
\hline (Constan) & 0,188 & 0,258 & & 0,727 & 0,500 \\
\hline LDR & $9,69 \mathrm{E}-005$ & 0,003 & 0,15 & 0,038 & 0,971 \\
\hline NIM & $-0,026$ & 0,026 & $-0,415$ & $-0,989$ & 0,368 \\
\hline Inflasi & 0,012 & 0,009 & 0,574 & 1,408 & 0,218 \\
\hline
\end{tabular}

Berdasarkan Tabel 10. hasil uji heteroskedastisitas, signifikansi setiap variabel independen lebih tinggi dari 5\%. Hal ini menunjukkan bahwa tidak ada variabel independen yang signifikan secara statistik memengaruhi residual dari model regresi. Dengan demikian, dapat disimpulkan bahwa tidak terdapat masalah heteroskedastisitas dalam model regresi.

Berdasarkan Tabel 11, didapat nilai $\mathrm{F}$ hitung sebesar 21.318 dengan signifikansi sebesar 0,003 . Nilai signifikansi uji $F$ yang lebih kecil dari $\alpha=0,05$ menunjukkan bahwa model regresi sudah fit sehingga bisa diterima. Nilai koefisien determinasi atau $\mathrm{R}$ Square $=0,927$. Koefisien determinasi sebesar 0,927ini dapat diinterpretasikan bahwa 92,7\% varians dari ROA disebabkan oleh 
variabel indipenden LDR, NIM, dan Inflasi, sedangkan 7.3\% sisanya dijelaskan oleh variabel lain yang tidak diteliti.

Tabel 11.

Hasil Uji F

\begin{tabular}{ccccccccc}
\hline \multirow{2}{*}{ Model } & R & R square & $\begin{array}{c}\text { Adjusted } \\
\text { R Square }\end{array}$ & $\begin{array}{c}\text { R Square } \\
\text { Change }\end{array}$ & F change & df1 & df2 & $\begin{array}{c}\text { Sig. F } \\
\text { Change }\end{array}$ \\
\hline & & & & & & & & \\
1 & $0,963 \mathrm{a}$ & 0,927 & 0,884 & 0,927 & 21,318 & 3 & 5 & 0,003 \\
\hline \multicolumn{2}{l}{ Sumber: Data diolah, 2018}
\end{tabular}

Uji t digunakan untuk mengetahui pengaruh masing-masing variabel bebas (LDR, NIM, dan Inflasi) secara parsial terhadap variabel terikat (ROA). Pada uji parsial digunakan taraf signifikansi 5\%. Apabila tingkat signifikansi $<5 \%$ maka hipotesis penelitian dapat diterima dan apabila tingkat signifikansi $>5 \%$, maka hipotesis penelitian ditolak.

Tabel 12.

Hasil Uji Parsial (Uji t)

\begin{tabular}{cccc}
\hline Model & Beta & Sig & Keterangan \\
\hline LDR & 0,302 & 0.066 & Tidak signifikan \\
NIM & 0,697 & 0.004 & Signifikan \\
Inflasi & 0,319 & 0.063 & Tidak Signifikan \\
\hline
\end{tabular}

Sumber: Data diolah, 2018

Berdasarkan Tabel 12. diperoleh nilai koefisien regresi variabel LDR dengan arah positif sebesar 0,697 dengan taraf signifikansi 0,066 lebih besar dari taraf $\alpha=0.05$ sehingga Ho diterima dan $\mathrm{H}_{1}$ ditolak yang menunjukkan bahwa LDR berpengaruh positif dan tidak signifikan terhadap ROA, sehingga dalam penelitian ini hipotesis pertama ditolak.

Berdasarkan Tabel 12. diperoleh nilai koefisien regresi variabel NIM dengan arah positif sebesar 0,187 dengan taraf signifikansi 0,004 lebih kecil dari taraf $\alpha=0.05$ yang menunjukkan bahwa NIM berpengaruh positif dan signifikan terhadap ROA, sehingga $\mathrm{H} 1$ dalam penelitian ini diterima.

Berdasarkan Tabel 12. diperoleh nilai koefisien regresi variabel Inflasi dengan arah positif sebesar 0,319 dengan taraf signifikansi 0,063 lebih besar dari taraf $\alpha=0.05$ yang menunjukkan bahwa Inflasi berpengaruh positif dan tidak signifikan terhadap ROA, sehingga $\mathrm{H} 1$ dalam penelitian ini ditolak.

Koefisien determinasi $\left(\mathrm{R}^{2}\right)$ digunakan untuk mengukur kemampuan model yang dibentuk dalam menerangkan variasi variabel terikatnya. Tabel 13 menunjukkan bahwa besarnya nilai $\mathrm{R}$ square adalah sebesar 0,927 . Hal ini berarti sebesar 92,7 persen variasi ROA dapat dijelaskan oleh variabel bebas LDR (X1), NIM (X2), dan Inflasi (X3) sedangkan 7,3 persen dijelaskan oleh variabel lain diluar model penelitian. 
Tabel 13.

Hasil Uji Koefisien Determinasi

\begin{tabular}{cccccc} 
Model & R & R square & $\begin{array}{c}\text { Adjusted R } \\
\text { Square }\end{array}$ & $\begin{array}{c}\text { Std. Error of } \\
\text { the Estimate }\end{array}$ & $\begin{array}{c}\text { R Square } \\
\text { Change }\end{array}$ \\
\hline 1 & 0,693 & 0,927 & 0,884 & 0,8771 & 0,927 \\
\hline Sumber: Data diolah, 2018 & & & &
\end{tabular}

Hipotesis dalam penelitian ini adalah LDR berpengaruh positif dan signifikan terhadap profitabilitas. Berdasarkan hasil pengujian pengaruh LDR $\left(\mathrm{X}_{1}\right)$ terhadap Profitabilitas $(\mathrm{Y})$ yang ditujukan pada Tabel 4.8 diketahui bahwa tingkat signifikan uji t sebesar 0.066 lebih besar daripada taraf nyata dalam penelitian ini yaitu $\alpha=0,05$ dengan nilai koefisien beta sebesar 0.302 . Nilai signifikansi ini menunjukkan bahwa LDR tidak berpengaruh terhadap Profitabilitas (ROA), sehingga hipotesis pertama yang menyatakan bahwa LDR berpengaruh positif dan signifikan terhadap profitabilitas Pada PT. Bank Pembangunan Daerah Bali Periode 2009-2017, ditolak.

Hasil penelitian yang menunjukkan pengaruh positif ini memiliki arti, jika terjadi peningkatan terhadap LDR maka profitabilitas (ROA) juga mengalami peningkatan. LDR yang semakin tinggi mengindikasikan bahwa semakin banyak dana pihak ketiga yang mampu disalurkan oleh PT. Bank Pembangunan Daerah Bali dalam bentuk kredit. Semakin tinggi atau besar dana dari pihak ketiga yang dapat dihimpun oleh perbankan dan disalurkan dalam bentuk kredit secara tepat, efesien dan hati-hati maka akan dapat meningkatkan pendapatan perbankan karena semakin tinggi LDR semakin besar juga untuk mencapai ROA. Ini karena jumlah dana yang diperlukan untuk membiayai kredit akan menjadi semakin besar. Pengaruh LDR yang positif tidak signifikan terhadap ROA menunjukkan bahwa walaupun LDR tinggi namun tidak memiliki dampak yang serius terhadap peningkatan ROA. Kondisi ini dapat terjadi karena besarnya penyaluran kredit tidak didukung oleh kualitas kredit yang baik, kualitas kredit yang buruk tersebut dapat mempengaruhi profitabilitas yang diperoleh (Prastiningtyas, 2010).

Hasil penelitian ini sejalan dengan hasil penelitian dari Pauzi (2011), Prastiyaningtyas (2010) Adnyani (2011), Fitriyana (2011), Sudiyatno dan Suroso (2010) dan Bernardin (2016) yang menyatakan bahwa LDR berpengaruh positif dan tidak signifikan terhadap ROA.

Hasil penelitian ini menunjukkan bahwa NIM memiliki pengaruh positif dan signifikan terhadap ROA pada PT. Bank Pembangunan Daerah Bali periode tahun 2009-2017 sehingga hipotesis kedua dalam penelitian ini yang menyatakan bahwa NIM berpengaruh positif dan signifikan terhadap profitabilitas pada PT. Bank Pembangunan Daerah Bali periode 2009-2017, diterima. Berdasarkan hasil pengujian pengaruh NIM $\left(\mathrm{X}_{2}\right)$ terhadap Profitabilitas (ROA) pada Tabel 4.7 dapat diketahui bahwa tingkat signifikan uji t sebesar 0,004 yang menunjukkan angka lebih kecil daripada taraf nyata dalam penelitian ini yaitu $\alpha=0,05$ dengan nilai koefisien regresi sebesar 0,697. Jadi hal ini menunjukkan bahwa NIM berpengaruh positif dan signifikan terhadap Profitabilitas (ROA). 
Hasil penelitian yang menunjukkan pengaruh positif ini memiliki arti, apabila terjadi peningkatan terhadap NIM maka profitabilitasnya (ROA) mengalami peningkatan. Dengan demikian besarnya NIM akan mempengaruhi laba rugi Bank yang pada akhirnya mempengaruhi kinerja bank tersebut. NIM merupakan rasio kemampuan manajemen bank dalam mengelola aktiva produktif untuk menghasilkan pendapatan bunga bersih semakin besar. Semakin tinggi NIM menunjukkan semakin efektif bank dalam penempatan aktiva perusahaan dalam bentuk kredit, sehingga ROA bank akan semakin meningkat. Atau dengan kata lain, semakin besar NIM suatu bank, maka semakin besar juga ROA yang diperoleh bank tersebut, yang berarti kinerja keuangan bank semakin membaik dan meningkat (Nadi, 2016). Kemampuan manajemen bank dalam menghasilkan bunga bersih berpengaruh terhadap tingkat pendapatan bank akan total assetnya. Bunga bersih merupakan salah satu komponen pembentuk laba (pendapatan), karena laba merupakan komponen pembentuk Return on Asset (ROA) maka secara tidak langsung jika pendapatan bunga bersih meningkat maka laba yang dihasilkan bank juga meningkat, sehingga akan meningkatkan profitabilitas dari perusahaan perbankan (Oktavianus, 2016). Bank Pembangunan Daerah Bali periode tahun 2009-2017 berada diatas 6\% sesuai dengan standar yang ditentukan oleh Bank Indonesia, hal ini berarti NIM yang dihasilkan sudah maksimal dan mampu untuk mengatasi kerugian.

Hasil penelitian ini sesuai dengan Lall (2014), Bilian dan Purwanto (2014), Kristianti dan Yovin (2016), Okavianus (2016), Avrita dan Pangestuti (2016), Nadi (2016) dan Dewi (2018), yang menunjukkan hasil bahwa NIM memiliki hubungan yang positif dan signifikan terhadap profitabilitas (ROA).

Hasil penelitian ini menunjukkan bahwa Inflasi memiliki pengaruh positif dan tidak signifikan signifikan terhadap ROA pada PT. Bank Pembangunan Daerah Bali periode tahun 2009-2017 sehingga hipotesis ketiga dalam penelitian ini yang menyatakan bahwa Inflasi berpengaruh negatif dan signifikan terhadap profitabilitas pada PT. Bank Pembangunan Daerah Bali periode 2009-2017, ditolak. Hasil penelitian yang menunjukkan pengaruh positif ini memiliki arti, apabila terjadi peningkatan terhadap Inflasi maka profitabilitasnya (ROA) mengalami peningkatan, hal ini menggambarkan bahwa PT. Bank Pembangunan Daerah Bali mampu megantisipasi inflasi sehingga menyebabkan meningkatnya laba perusahaan. Kegiatan yang dilakukan oleh PT. Bank Pembangunan Daerah Bali dalam mengatasi inflasi sama halnya seperti Bank Indonesia yaitu ketika inflasi meningkat, Bank Indonesia akan meningkatkan suku bunganya meningkatkan bagi hasil deposito maupun pembiayaan yang akan menimbulkan ketertarikan dari para nasabah seperti yang akan berdampak pada peningkatan kinerja keuangan bank tersebut walaupun tidak signifikan. Hasil penelitian ini sesuai dengan Alim (2013) dan Prastowo et al. (2018) yang menyatakan bahwa Inflasi berpengaruh positif dan tidak signifikan terhadap ROA.

Penelitian ini memberikan informasi penting bagi PT. Bank Pembangunan Daerah Bali untuk dapat memaksimumkan profitabilitasnya. Berdasarkan hasil penelitian, LDR berpengaruh positif dan tidak signifikan terhadap ROA, hal ini berarti peningkatan penyaluran kredit akan meningkatkan pendapatan yang diterima PT. Bank Pembangunan Daerah Bali. Peningkatan likuiditas tetap harus 
disesuaikan dengan batas aman Bank Indonesia. Bank perlu menyediakan likuiditas dalam jumlah cukup untuk dapat beroperasi secara efisien dan memenuhi kewajiban pada kreditur yang sudah jatuh tempo dan yang secara tibatiba melakukan penarikan. Penting bagi bank untuk mempunyai gambaran kondisi likuiditas dengan melakukan analisis rasio likuiditas yang didasarkan pada data likuiditas yang sudah berlalu.

Berdasarkan hasil penelitian, NIM berpengaruh positif dan signifikan terhadap ROA, hal ini berarti Setiap peningkatan pendapatan bunga bersih, yang merupakan selisih antara total biaya bunga dengan total pendapatan bunga mengakibatkan bertambahnya laba sebelum pajak, yang pada akhirnya mengakibatkan peningkatan Return On Assets PT. Bank Pembangunan Daerah Bali.

Untuk meningkatkan profitabilitas, bank juga perlu memperhatikan faktor eksternal dari bank itu sendiri yaitu Inflasi. Berdasarkan hasil penelitian ini Inflasi berpengaruh positif dan tidak signifikan terhadap ROA, hal ini menggambarkan bahwa PT. Bank Pembangunan Daerah Bali dapat megantisipasi inflasi sehingga menyebabkan meningkatnya laba perusahaan. Kegiatan yang dilakukan oleh PT. Bank Pembangunan Daerah Bali dalam mengatasi inflasi sama halnya seperti Bank Indonesia yaitu ketika inflasi meningkat, Bank Indonesia akan meningkatkan suku bunganya meningkatkan bagi hasil deposito maupun pembiayaan yang akan menimbulkan ketertarikan dari para nasabah seperti yang akan berdampak pada peningkatan kinerja keuangan bank tersebut.

\section{SIMPULAN}

LDR berpengaruh positif dan tidak signifikan terhadap profitabilitas PT. Bank Pembangunan Daerah Bali Periode 2009-2017. Hal ini berarti semakin tinggi dana pihak ketiga yang disalurkan maka semakin tinggi pula pendapatan yang dapat dicapai oleh PT. Bank Pembangunan Daerah Bali. NIM berpengaruh positif dan signifikan terhadap profitabilitas PT. Bank Pembangunan Daerah Bali Periode 2009-2017. Hal ini berarti semakin tinggi pendapatan bunga bersih yang diperoleh maka semakin tinggi pula keuntungan yang dapat dicapai PT. Bank Pembangunan Daerah Bali.

Inflasi berpengaruh positif dan tidak signifikan terhadap profitabilitas PT. Bank Pembangunan Daerah Bali Periode 2009-2017. Hal ini berarti semakin tinggi tingkat inflasi yang terjadi, maka semakin tinggi pula keuntungan yang dapat dicapai PT. Bank Pembangunan Daerah Bali.

PT. Bank Pembangunan Daerah Bali disarankan untuk tetap memperhatikan tingkat likuiditas dan pendapatan bunga bersih yang dimiliki dan tingkat inflasi yang terjadi agar PT. Bank Pembangunan Daerah Bali mampu memaksimalkan profitabilitasnya. PT. Bank Pembangunan Daerah Bali diharapkan mempunyai tingkat likuiditas yang tinggi tetapi tetap pada batas aman LDR yang telah ditentukan oleh Bank Indonesia. Bank harus mampu memproyeksikan kebutuhan dana dan menyediakan likuiditas dalam jumlah cukup untuk dapat beroperasi secara efisien dan memenuhi kewajiban pada kreditur karena penyaluran kredit merupakan aktivitas utama bagi perbankan untuk mendapatkan laba dan meningkatkan profitabilitas. PT. Bank Pembangunan Daerah Bali diharapkan 
mampu mengantisipasi inflasi yang terjadi seperti menurunkan suku bunga kredit sehingga dana dari pihak ketiga tetap dapat dikumpulkan dan dapat meningkatkan laba perusahaan.

Variabel yang digunakan dalam penelitian ini hanya terbatas pada variabel Loan to Deposit Ratio, Net Interest Margin, Inflasi, dan Profitabilitas (ROA). Disarankan kepada peneliti selanjutnya untuk mempertimbangkan varibel-variabel lain yang tidak dicantumkan dalam penelitian ini, seperti Capital Adequacy Ratio (CAR), BOPO, Ukuran Bank, dan Suku Bunga sebagai tambahan refrensi terhadap variabel yang diteliti.

\section{REFERENSI}

Acaravci, S. K., \& Calim, A. A. (2013). Turkish Banking Sector's Profitability Factors. International Journal of Economics and Financial Issues, 3(1), 2741. Retrieved from https://www.econjournals.com/index.php/ijefi/ article/view/343/pdf

Adnyani, L. R. (2011). Faktor-faktor Yang Mempengaruhi Profitabilitas (ROA). Universitas Diponegoro Semarang. Retrieved from http://eprints.undip.ac.id/ 28747/1/Skripsi11.pdf

Alim, S. (2013). Analisis Pengaruh Inflasi dan BI Rate Terhadap Return On Assets (ROA) Bank Syariah Di Indonesia. Jurnal Ekonomi Modernisasi, 10(3), 201-220. Retrieved from http://ejournal.unikama.ac.id/index.php/JEKO/ article/view/785/pdf_80

Alper, D., \& Anbar, A. (2011). Bank Specific and Macroeconomic Determinants of Commercial Bank Profitability: Empirical Evidence from Turkey. Business and Economics Research Journal, 2(2), 139-152. Retrieved from https://papers.ssrn.com/sol3/Delivery.cfm/SSRN_ID1831345_code1593442 .pdf? abstractid $=1831345 \&$ mirid $=1$

Alshatti, A. S. (2015). The Effect of the Liquidity Management on Profitability in the Jordanian Commercial Banks. International Journal of Business and Management, 10(1), 62-71. https://doi.org/10.5539/ijbm.v10n1p62

Anggadini, S. D., \& Tarsiah, E. (2017). The Influence of Net Profit Margin And Current Ratio. Jurnal Riset Akuntansi, 9(2), 37-43. Retrieved from https://ojs.unikom.ac.id/index.php/jira/article/view/539

Anjani, D. A., \& Purnawati, N. K. (2014). Pengaruh NPL, Likuiditas, dan Rentabilitas Terhadap Kecukupan Modal Pada Sektor Perbankan Terdaftar di Bursa Efek Indonesia. E-Journal Manajemen Unud, 1(1), 1140-1155. Retrieved from https://ojs.unud.ac.id/index.php/Manajemen/article/view/ $7592 / 6360$

Avrita, R. D., \& Pangestuti, I. R. D. (2016). Analisis Pengaruh CAR, NPL, LDR, NIM, dan BOPO Terhadap Profitabilitas Bank. Diponegoro Journal of Management, 5(2), 1-13. $\quad$ Retrieved from https://ejournal3.undip.ac.id/index. php/djom/article/download/13964/13500 
Bernardin, D. E. Y. (2016). Pengaruh CAR dan LDR Terhadap Return On Assets. Ecodomica, 4(2), 232-241. Retrieved from https://ejournal.bsi.ac.id/ejurnal/ index.php/ecodemica/article/view/334/PDF

Bilian, F., \& Purwanto. (2014). Analisis Pengaruh CAR, NIM, BOPO, dan LDR Terhadap Profitabilitas Bank Persero. Firm Journal of Management Studies, 2(1), 155-168. Retrieved from http://e-journal.president.ac.id/presunivojs/ index.php/FIRM-JOURNAL/article/download/157/85

Chou, T., \& Buchdadi, A. D. (2016). Bank Performance and Its Underlying Factors: A Study of Rural Banks in Indonesia. Accounting and Finance Research, 5(3), 55-63. https://doi.org/10.5430/afr.v5n3p55

Dendawijaya, L. (2005). Manajemen Perbankan. Jakarta: Ghalia Indonesia.

Dewi, O. R. (2018). Pengaruh Dana Pihak Ketiga, Inflasi, BI Rate dan Kurs Terhadap Profitabilitas Perbankan Syariah Di Indonesia Periode 20132017. Universitas Islam Negeri Raden Intan Lampung. Retrieved from http://repository.radenintan.ac.id/3956/1/pdf.pdf

Dietrich, A., \& Wanzenried, G. (2009). What Determines the Profitability of Commercial Banks? New Evidence from switzerland. Determinants of Banking Profitability, 1(1), 1-39. Retrieved from http://citeseerx.ist.psu.edu/ viewdoc/download?doi=10.1.1.498.7051\&rep=rep1\&type=pdf

Diva. (2013). Pengaruh Rasio CAR, NPL, BOPO, LDR, dan NIM Terhadap Profitabilitas Perbankan (Studi Pada Bank Umum Di Indonesia Yang Terdaftar Di Bursa Efek Indonesia Periode 2007-2012). Universitas Widyatama. Retrieved from https://repository.widyatama.ac.id/xmlui/ handle/123456789/2751

Duraj, B., \& Moci, E. (2015). Factors Influencing The Bank Profitability Empirical Evidencing From Albania. Asian Economic and Financial Review, 5(3), 483-494. https://doi.org/10.18488/journal.aefr/2015.5.3/102.3.483.494

Dwijayanti, F., \& Naomi, P. (2016). Analisis Pengaruh Inflasi, BI Rate, dan Nilai Tukar Mata Uang terhadap Profitabilitas Bank Periode 2003-2007. Karisma, 3(2), 87-98. Retrieved from https://www.researchgate.net/publication/267364463_Analisis_Pengaruh_In flasi_BI_Rate_dan_Nilai_Tukar_Mata_Uang_terhadap_Profitabilitas_Bank Periode_2003-2007_Analysis_of_Effect_of_Inflation BI_Rate_and_Exchange_Rate_on_Bank_Profitability_Period_20032/download

Fahmi, I. (2016). Pengantar Manajemen Keuangan Teori dan Soal Tanya Jawab. Bandung: Alfabeta.

Fitriyana, A. (2011). Analisis Pengaruh Rasio Kecukupan Modal, Likuiditas, 
Kredit Bermasalah, Equity Ratio Asset Dan Waktu Deposit Ratio Terhadap Return On Assets Bank. Universitas Diponegoro Semarang.

Floros, C., \& Tan, Y. (2012). Bank profitability and inflation: the case of China. Journal of Economic Studies, 39(6), 675-696. https://doi.org/10.1108/01443581211274610

Hartono. (2017). Effect of Capital Adequacy Ratio (CAR), Loan to Deposit ratio (LDR) and Non Performing Loan (NPL) to Return On Assets (ROA) Listed In Banking In Indonesia Stock Exchange. International Journal of Education and Research, 5(1), 69-80. Retrieved from https://www.ijern.com/journal/2017/ January-2017/06.pdf

Hartono, J. (2016). Teori Portofolio dan Analisis Investasi (10th ed.). Yogyakarta: BPFE.

Harun, U. (2016). Pengaruh Ratio-Ratio Keuangan CAR, LDR, NIM, BOPO, NPL Terhadap ROA. Jurnal Riset Bisnis Dan Manajemen, 4(1), 67-82. Retrieved from https://ejournal.unsrat.ac.id/index.php/jrbm/article/view/12352/11929

Hidayati, A. N. (2014). Pengaruh Inflasi, Bi Rate dan Kurs Terhadap Profitabilitas Bank Syariah Di Indonesia. Jurnal Ekonomi Syariah, 1(1), 72-91. https://doi.org/10.21274/an.2014.1.1.72-97

Irfan, M., Santoso, B., \& Effendi, L. (2016). Pengaruh Partisipasi Anggaran terhadap Senjangan Anggaran dengan Asimetri Informasi, Penekanan Anggaran dan Komitmen Organisasional sebagai Variabel Pemoderasi. Jurnal Akuntansi Dan Investasi, 17(2), 158-175. https://doi.org/10.18196/jai. 2016.0052.158-175

Ismaulina, \& Zulfadhli. (2016). Effect of Capital Adequacy, Liquidity and Operational Efficiency to Profitability In Bank Syariah Mandiri (Period 2008 s.d 2015). Jurnal Ilmiah Syariah, 15(1), 43-54. Retrieved from https://media.neliti.com/media/publications/93011-EN-effect-of-capitaladequacy-liquidity-and.pdf

Kalengkongan, G. (2013). Tingkat Suku Bunga Dan Inflasi Pengaruhnya Terhadap Return On Asset (ROA) Pada Industri Perbankan Yang Go Public Di Bursa Efek Indonesia. Jurnal EMBA, 1(4), 737-747. Retrieved from https://media.neliti.com/media/publications/1827-ID-tingkat-suku-bungadan-inflasi-pengaruhnya-terhadap-return-on-asset-roa-pada-ind.pdf

Karuniawati, R. (2017). Pengaruh Non Performing Loan dan Loan To Deposit Ratio Terhadap Return On Asset. Akademika, 15(1), 32-39. Retrieved from http://jurnal.stieimalang.ac.id/index.php/JAK/article/download/72/29

Kasmir. (2012). Analisis Laporan Keuangan. Jakarta: PT Raja Grafindo Persada.

Kasmir. (2013). Bank dan Lembaga Keuangan Lainnya. Jakarta: Raja Grafindo Persada. 
Kristianti, R. A., \& Yovin. (2016). Factors Affecting Bank Performance : Cases of Top 10 Biggest Government and Private Banks in Indonesia in 2004 - 2013. Review of Integrative Business and Economics Research, 5(4), 371-378. Retrieved from http://sibresearch.org/uploads/3/4/0/9/34097180/riber_s16163_371-378.pdf

Lall, P. (2014). Factors affecting U . S . Banking Performance : Evidence From the 2007-2013 Financial Crisis. International Journal of Economics, Finance and Management, 3(6), 282-295. Retrieved from http://www.ejournalofbusiness. org/archive/vol3no6/vol3no6_4.pdf

Mankiw, N. G., Quah, E., \& Peter, W. (2012). Pengantar Ekonomi Makro. Jakarta: Salemba Empat.

Manurung, A. H. (2015). Effects of Bonds Issuance on Banking Performance. Journal of Applied Finance \& Banking, 5(5), 113-124. Retrieved from http://www.scienpress.com/Upload/JAFB\%2FVol 5_5_7.pdf

Masdupi, E., \& Defri. (2012). Pengaruh Capital Adequacy Ratio (CAR), Likuiditas dan Efisiensi Operasional Terhadap Profitabilitas Perusahaan Perbankan yang Terdaftar di BEI. Jurnal Kajian Manajemen Bisnis, 1(1), 118.

Retrieved from http://ejournal.unp.ac.id/index.php/jkmb/article/download/4767/3731

Miadalyni, P. D., \& Dewi, S. K. S. (2013). Pengaruh Loan to Deposit Ratio, Loan to Asset Ratio, Capital Adequacy Ratio dan Kualitas Aktiva Produktif Terhadap Profitabilitas Pada PT. Bank Pembanngunan Daerah Bali Kantor Pusat Denpasar. E-Journal Manajemen Unud, 2(12), 1542-1558. Retrieved from https://ojs.unud.ac.id/index.php/Manajemen/article/view/5927

Mismiwati, M. (2016). Pengaruh CAR, NIM, BOPO, LDR dan NPL Terhadap ROA. I-Finance, 2(1), 55-74. Retrieved from http://jurnal.radenfatah.ac.id/ index.php/I-Finance/article/view/1009

Muda, M., Shaharuddin, A., \& Embaya, A. (2013). Comparative Analysis of Profitability Determinants of Domestic and Foreign Islamic Banks in Malaysia. International Journal of Economics and Financial Issues, 3(3), 559-569. Retrieved from http://www.econjournals.com/index.php/ ijefi/article/view/462/pdf

Nadi, L. (2016). Analisis Pengaruh CAR, NPL dan NIM terhadap Profitabilitas Perbankan yang Terdaftar di Bursa Efek Indonesia. Jurnal Ilmiah Akuntansi Universitas Pamulang2, 4(2), 958-977. https://doi.org/http://dx.doi.org/ 10.32493/jiaup.v4i2.183

Oktavianus, C. M. (2016). Pengaruh Capital Adequacy Ratio, Loan To Deposit Ratio, Non Performing Loan dan Net Interest Margin Terhadap Profitabilitas Perusahaan Perbankan Di Bursa Efek Indonesia. E-Jurnal Katalogis, 4(8), 1-12. Retrieved from https://media.neliti.com/media/publications/158075-ID-none.pdf 
Pamularsih, D. (2015). No Pengaruh LDR, NPL, NIM, BOPO, CAR dan Suku Bunga Terhadap Profitabilitas Pada Sektor Perbankan Yang Terdaftar Di Bursa Efek Indonesia Periode Tahun 2009-2013. Jurnal of Accounting, 1(1), 1-20. Retrieved from https://jurnal.unpand.ac.id/index.php/AKS/article /view/190/186

Pauzi, A. (2011). Analisis Dana Pihak Ketiga, Non Performing Loan, Capital Adequecy Ratio, Dan Loan To Deposit Ratio Terhadap Return On Assets Serta Implikasinya Terhadap Penyaluran Kredit Pada Bank Persero. Universitas Islam Negeri Syarif Hidayatullah Jakarta. Retrieved from http://repository.uinjkt.ac.id/dspace/bitstream/123456789/2835/1/AGUS PAUZI-FEB.pdf

Peling, I. A. A., \& Sedana, I. B. P. (2018). Pengaruh LDR, NPL, dan BOPO Terhadap Profitabilitas Pada PT. BPD Bali Periode Tahun 2009-2016. EJournal Manajemen Unud, 7(6), 2999-3026. https://doi.org/https://doi.org/10.24843/EJMUNUD.2018.v7.i06.p

Prasanjaya, A. A. Y., \& Ramanantha, I. W. (2013). Analisis Pengaruh Rasio CAR, BOPO, LDR dan Ukuran Perusahaan Terhadap Profitabilitas Bank yang Terdaftar di BEI. E-Journal S1 Akuntansi Universitas Udayana2, 4(1), 230-245. Retrieved from http://download.portalgaruda.org/article.php? article $=82247 \& v a l=986$

Prasetyo, D. A., \& Darmayanti, N. P. A. (2015). Pengaruh Risiko Kredit, Likuiditas, Kecukupan Modal, Dan Efisiensi Operasional Terhadap Profitabilitas Pada PT BPD Bali. E-Jurnal Manajemen Unud, 4(9), 25902617. Retrieved from https://media.neliti.com/media/publications/253294pengaruh-risiko-kredit-likuiditas-kecuku-a075bee1.pdf

Prastiningtyas, F. (2010). Faktor-Faktor Yang Mempengaruhi Profitabilitas Perbankan (Studi Pada Bank Umum Go Public Yang Listed Di Bursa Efek Indonesia Tahun 2005-2008). Universitas Diponegoro Semarang. Retrieved from http://eprints.undip.ac.id/22950/1/SKRIPSI.pdf

Prastowo, P. R., Malavia, R., \& Wahono, B. (2018). Analisis Pengaruh Inflasi, Suku Bunga dan Nilai Tukar Terhadap Profitabilitas Perbankan. E-Jurnal Riset Manajemen, 7(16), 27-41. Retrieved from http://riset.unisma.ac.id/ index.php/jrm/article/viewFile/1324/1322

Puspitasari, D. M., Setiadi, N. J., \& Rizkiyanti, N. (2015). Implementation Of The Indonesia banking Architecture As A Blueprint Of The Direction And Order Of The National banking System: Emprical Study Of Indonesiaan Commercial Banking. Journal The Winners, 16(1), 6-14. Retrieved from http://journal.binus.ac.id/index.php/winners/article/download/1538/1355

Septiani, R., \& Lesatari, P. V. (2016). Pengaruh NPL dan LDR Terhadap Profitabilitas dengan CAR Sebagai Variabel Mediasi Pada PT. BPR Pasarraya Kuta. E-Journal Manajemen Unud, 5(1), 293-324. Retrieved 
from https://ojs.unud.ac.id/index.php/Manajemen/article/view/15907

Sudiyanto, B., \& Suroso, J. (2010). Analisis pengaruh dana Pihak Ketiga, BOPO, CAR, LDR Dan Terhadap costs kos Keuangan PADA Sektor Perbankan Yang pergi di public Bursa Efek Indonesia (BEI) (Periode 2005-2008). Dinamika Keuangan Dan Perbankan, 2(2), 125-137. Retrieved from https://www.unisbank.ac.id/ojs/index.php/fe1/article/view/187

Sulindawati, N. L. G. E., Yuniarta, G. A., \& Purnawati, G. A. (2017). Manajemen Keuangan Sebagai Dasar Pengambilan Keputusan Bisnis. Depok: Rajawali Press.

Ubaidillah. (2016). Analisis Faktor-Faktor Yang Mempengaruhi Profitabilitas Bank Syariah Di Indonesia. Jurnal Ekonomi Islam, 4(1), 151-188. Retrieved from http://ejournal.iainpurwokerto.ac.id/index.php/eljizya/article/view/978/789

Wiagustini, N. L. P. (2014). Manajemen Keuangan (1st ed.). Denpasar: Udayana University Press.

Wibowo, E. S., \& Syaichu, M. (2013). Analisis Pengaruh Suku Bunga, Inflasi, CAR, BOPO, NPF Terhadap Profitabilitas Bank Syariah. Diponegoro Journal of Management, 2(2), 1-10. Retrieved from https://ejournal3.undip.ac.id/ index.php/djom/article/download/2651/2643

Widowati, S. A., \& Suryono, B. (2015). Pengaruh Rasio Keuangan Terhadap Profitabilitas Perbankan Di Indonesia. Jurnal Ilmu Dan Riset Akuntansi, 4(6), 1-15. Retrieved from http://jurnal.uinsu.ac.id/index.php/tawassuth/ article/download/1703/1366

Zuniarti, I. (2013). Analisis Pengaruh Suku Bunga Dan Tingkat Inflasi Terhadap PT. Bank Rakyat Indonesia (Persero) Tbk Periode 2008-2012. Perspektif, 11(1), 49-59. Retrieved from https://scholar.google.co.id/citations?user= jv1m8TEAAAAJ\&hl=id 